\title{
EKONOMICZNO-PRAWNA ANALIZA RACJONALNOŚCI REGULACJI DOTYCZACCYCH POWIĘKSZANIA OBSZARÓW PARKÓW NARODOWYCH W POLSCE - ZARYS PROBLEMATYKI
}

\section{Wprowadzenie}

Ograniczoność zasobów pozostających do dyspozycji ludzi oraz wręcz nieograniczoność potrzeb determinuje ludzkie decyzje ekonomiczne. Człowiek musi racjonalnie gospodarować posiadanymi zasobami i dokonywać wyborów poprzez umiejętne wyważenie korzyści i kosztów alternatywnych. Tradycyjnie ekonomia dzieli czynniki produkcji na: zasoby ludzkie, zasoby naturalne oraz zasoby kapitałowe. Istotnym zasobem naturalnym jest ziemia. ${ }^{1}$ Zasoby naturalne mogą być nie tylko rozpatrywane jako determinanty prowadzenia działalności gospodarczej, ale również jako strategiczne zasoby naturalne z punktu widzenia ochrony przyrody, ${ }^{2}$ w szczególności w formie parków narodowych.

Park narodowy to najważniejsza i jedna z najstarszych prawnych (w myśl art. 8a ustawy z dnia 16 kwietnia 2004 r. o ochronie przyrody park narodowy jest państwową osobą prawną ${ }^{3}$, obszarowych form ochrony przyrody w Polsce. Ich początki w naszym kraju sięgają lat 20. XX wieku. Jako pierwszy został powołany do życia Białowieski Park Narodowy w 1932 roku, na bazie terenów objętych uprzednio ochroną $\mathrm{w}$ ramach rezerwatu częściowego. Obecna ustawa o ochronie przyrody z dnia 16 kwietnia 2004 roku definiuje park narodowy jako obszar wyróżniający się szczególnymi wartościami przyrodniczymi, naukowymi, społecznymi, kulturo-

M. Rekowski, Mikroekonomia, Poznań 2005, s. 9-20.

P.A. Samuelson, W.D. Nordhaus, Ekonomia. Tom 1, Warszawa 2004, s. 476.

Ustawa z dnia 16 kwietnia 2004 r. o ochronie przyrody (t.j. Dz.U. z 2009 r. Nr 151, poz. 1220 z późn. zm.) 
wymi i edukacyjnymi, o powierzchni nie mniejszej niż 1000 ha, na którym ochronie podlega cała przyroda oraz walory krajobrazowe. Tworzy się go w celu zachowania różnorodności biologicznej, zasobów, tworów i składników przyrody nieożywionej i walorów krajobrazowych, przywrócenia właściwego stanu zasobów i składników przyrody oraz odtworzenia zniekształconych siedlisk przyrodniczych, siedlisk roślin, siedlisk zwierząt lub siedlisk grzybów.

Zasoby przyrodnicze parków narodowych zaliczane są do strategicznych zasobów naturalnych Polski zgodnie z art. 1 pkt 5 ustawy z dnia 6 lipca 2001 r. o zachowaniu narodowego charakteru strategicznych zasobów naturalnych kraju. ${ }^{4}$

Autorzy w pełni zdają sobie sprawę, iż niniejszy artykuł w żadnym razie nie wyczerpuje złożoności tematyki, a stanowi jedynie jej zarys i przyczynek do szerszej dyskusji.

\section{Gospodarcze i środowiskowe skutki powiększania obszarów parków narodowych}

Dla podmiotów prowadzących działalność gospodarczą, czyli w myśl art. 2 ustawy o swobodzie działalność gospodarczej, zarobkową działalnością wytwórczą, budowlaną, handlową, usługową oraz poszukiwaniem, rozpoznawaniem i wydobywaniem kopalin ze złóż, a także działalnością zawodową, wykonywaną w sposób zorganizowany i ciągły ${ }^{5}$ prowadzenie tejże działalności na terenie parków narodowych lub w obszarze otuliny tychże parków jest mocno problematyczne. ${ }^{6}$

Oczywiście pod pojęciem działalności gospodarczej na potrzeby niniejszego artykułu należy również rozumieć działalność wytwórczą w rolnictwie w zakresie upraw rolnych oraz chowu i hodowli zwierząt, ogrodnictwa, warzywnictwa, leśnictwa i rybactwa śródlądowego, a także wynajmowania przez rolników pokoi, sprzedaży posiłków domowych i świadczenia w gospodarstwach rolnych innych usług związanych z pobytem turystów oraz wyrobu wina przez producentów będących rolnikami wyrabiającymi mniej niż 100 hektolitrów wina w ciągu roku gospodarczego, mimo iż art. 3 ustawy o swobodzie działalności gospodarczej wyłącza zastosowanie przedmiotowej ustawy wobec tych typów działalności. W ekonomicznym jednakże ujęciu przedmiotowe rodzaje aktywności są prowadzeniem działalności gospodarczej. Podobnie zresztą tę kwestię ujmuje judykatura. ${ }^{7} \mathrm{Z}$ uwagi na charakter parków narodowych i ich otulin nie można powyższych form uzyskiwania dochodu uznać za mało znaczące, zwłaszcza tzw. agroturystykę.

\footnotetext{
$4 \quad$ Ustawa z dnia 6 lipca 2001 r. o zachowaniu narodowego charakteru strategicznych zasobów naturalnych kraju (Dz.U. z 2001 r. Nr 97, poz. 1051).

Postanowienie SN z dnia 2 lutego 2009 roku, sygn. akt V KK 308/08, LEX nr 498031, (dostęp: 21.01.2013 r.).

E. Symonides, Ochrona przyrody, Warszawa 2008, s. 408-409.

Wyrok NSA z dnia 29 sierpnia 2007 roku, sygn. akt II OSK 1618/06, LEX nr 364703, (dostęp: 21.01.2013 r.).
} 
Ekonomiczno-prawna analiza racjonalności regulacji dotyczących powiększania obszarów...

Tabela 1. Produkt Krajowy Brutto Polski w latach 2000-2010

\begin{tabular}{||l|c|c|c|c|c|c|c|}
\hline \multirow{2}{*}{ Wyszczególnienie } & 2000 & 2005 & 2009 & 2010 & 2000 & 2010 \\
\cline { 2 - 8 } & \multicolumn{5}{|c|}{ w mln zł } & \multicolumn{2}{c|}{ w odsetkach } \\
\hline OGÓŁEM & 744378 & 983302 & 1343366 & 1415385 & 100,0 & 100,0 \\
\hline $\begin{array}{l}\text { W tym wartość dodana brutto } \\
\text { w tym: }\end{array}$ & 662224 & 866329 & 1193691 & 1245935 & 89,0 & 88,0 \\
\hline Rolnictwo, łowiectwo, leśnictwo & 32625 & 39051 & 43383 & 43950 & 4,4 & 3,1 \\
\hline $\begin{array}{l}\text { Przemysł } \\
\text { w tym: }\end{array}$ & 158750 & 213836 & 289797 & 305944 & 21,4 & 21,6 \\
\hline Górnictwo & 15942 & 21960 & 25889 & 32724 & 2,2 & 2,3 \\
\hline Przetwórstwo przemysłowe & 122595 & 160374 & 220728 & 230463 & 16,5 & 16,3 \\
\hline $\begin{array}{l}\text { Wytwarzanie i zaopatrywanie w energię } \\
\text { elektryczną, gaz, wodę }\end{array}$ & 20213 & 31502 & 43180 & 42757 & 2,7 & 3,0 \\
\hline Budownictwo & 51225 & 52207 & 89047 & 88351 & 6,9 & 6,3 \\
\hline Handel i naprawy & 128877 & 164154 & 221518 & 234837 & 17,3 & 16,6 \\
\hline Na 1 mieszkańca (w złotych) & 19458 & 25767 & 35210 & 37065 & $x x$ & $x x$ \\
\hline
\end{tabular}

Źródło: Mały rocznik statystyczny 2011, GUS, Warszawa 2011, s. 475.

W świetle powyższych danych statystycznych, opartych na Polskiej Klasyfikacji Działalności, w przeważającej części siła polskiej gospodarki nie tkwi w tych sferach działalności gospodarczej, które stanowiłyby zagrożenie dla środowiska naturalnego, w tym najbardziej form ochrony tego środowiska, jakimi są parki narodowe wraz z ich otulinami. Jakkolwiek przemysł stanowi nadal znaczący składnik PKB, jednak głównie jest to obecnie rozbudowany przemysł przetwórczy, w coraz większym stopniu oparty na nowoczesnych, innowacyjnych i mało inwazyjnych dla środowiska technologiach produkcji. Większość Polaków jest zatrudniona w sektorze usług $(55,8 \%){ }^{8}$

Parki narodowe i ich otuliny niewątpliwie ograniczają znacznie możliwość prowadzenia części działalności gospodarczej, w szczególności poprzez konieczność uzyskiwania zgody dyrektorów parków narodowych na uchwalanie i zmienianie miejscowych planów zagospodarowania przestrzennego, jednakże są one często niezbędne dla ocalenia różnorodności biologicznej. ${ }^{9}$

Ochrona różnorodności biologicznej wymaga systemowego podejścia do procesów i struktur ekologicznych. Należy działalnością konserwatorską otaczać całe ekosystemy oraz występujące $\mathrm{w}$ nich zależności. Parki narodowe pełnią funkcję ochronną we właściwy, holistyczny sposób. Pomagają zachować różnorodność ga-

$8 \quad$ Mały rocznik statystyczny 2011, GUS, Warszawa 2011, s. 527.

9 M. Zgorzelski, Uwagi na temat roli otulin w polskim, przestrzennym systemie obszarów chronionych, „Prace i Studia Geograficzne" 2011, T. 46, s. 201-206. 
tunkową oraz umożliwiają prowadzenie badań naukowych na temat z pogranicza ekologii, zoologii, botaniki, fitosocjologii itp. ${ }^{10}$

Powiększenie obszaru parku narodowego może stworzyć bardziej dogodne warunki ochronne dla migrujących gatunków zwierząt, których zasięg występowania obejmuje duże areały. Obszary objęte ochroną stanowią potencjalną, optymalną drogę migracji zwierząt, a przez to sprawniejszy przepływ genów, czy też dostęp do dodatkowych zasobów pokarmowych. Zwiększenie powierzchni parku narodowego stwarza również prawdopodobieństwo skuteczniejszej ochrony bioróżnorodności na poziomie ekosystemowym, obejmującym zróżnicowane systemy ekologiczne, występujące na danym obszarze. ${ }^{11}$ Oprócz zwiększenia efektywności ochrony gatunkowej, istotnym faktem jest również sprawniejsza ochrona siedlisk zwierząt, w tym wielu gatunków rzadkich i prawnie chronionych.

\section{Procedury powiększania parków narodowych w świetle ustawodawstwa polskiego}

Kluczowym aspektem związanym z powiększaniem parków narodowych jest zagadnienie wywłaszczenia gruntów pod realizację tegoż celu publicznego.

Konstytucja RP z 1997 roku w art. 64 ust. 3 w związku z art. 21 tejże Konstytucji daje wyraz ochronie prawa własności wprost stwierdzając, iż wywłaszczenie możliwe jest jedynie, gdy następuje: na podstawie ustawy, gdy dokonywane jest na cele publiczne i za słusznym odszkodowaniem.

Podstawowe regulacje ustawowe w zakresie wywłaszczania nieruchomości zawarte są w ustawie z dnia 21 sierpnia 1997 roku o gospodarce nieruchomościami, ${ }^{12}$ aczkolwiek istnieje liczna grupa ustaw zawierających przepisy specjalne w zakresie wywłaszczeń, w szczególności ustawa z dnia 28 marca 2003 r. o transporcie kolejowym. ${ }^{13} \mathrm{~W}$ praktyce zdarzają się niezależne od siebie przypadki, szczególnie w odniesieniu do bardziej rozległych nieruchomości, wywłaszczania różnych części tej samej nieruchomości na podstawie różnych ustaw, tak więc można wyobrazić sobie sytuację, gdy część nieruchomości zostanie wywłaszczona pod rozbudowę parku narodowego, zaś inna część np. na cele przebudowy istniejącej linii kolejowej.

W zakresie omawianej problematyki powiększania obszarów parków narodowych zasadniczo nastąpiło w art. 7 ust. 2 ustawy z dnia 16 kwietnia 2004 r. o ochronie przyrody ustawowe odesłanie zewnętrzne do, wspomnianej już, ustawy o gospodarce nieruchomościami. Ponadto w art. 7 ust. 1 ustawy o ochronie przyrody

10 R. Olaczek, Słownik szkolny, ochrona przyrody i środowiska, s. 181-182.

11 W. Goetel, Parki narodowe w Polsce, [w:] W. Szafer (red.), Ochrona przyrody. Rocznik 26, Kraków 1959, s. 273.

12 Ustawa z dnia 21 sierpnia 1997 roku o gospodarce nieruchomościami (tekst jednolity: Dz.U. z 2010 r. Nr 102 , poz. 651 z późn. zm.).

13 Ustawa z dnia 28 marca 2003 r. o transporcie kolejowym (tekst jednolity: Dz.U. z 2007 r. Nr 16, poz. 94 z późn. $\mathrm{zm}$.). 
Ekonomiczno-prawna analiza racjonalności regulacji dotyczących powiększania obszarów...

uznano za cel publiczny utworzenie lub powiększenie obszaru parku narodowego lub rezerwatu przyrody. Mamy tutaj do czynienia ze swoistego rodzaju ustawowym superfluum, albowiem z kolei w samej ustawie o gospodarce nieruchomościami w art. 6 ust. 9b jako cel publiczny uznano ochronę zagrożonych wyginięciem gatunków roślin i zwierząt lub siedlisk przyrody.

Tak więc stosując art. 112 ust. 2 i 3 ustawy o gospodarowaniu nieruchomościami w związku z art. 7 ust. 2 ustawy o ochronie przyrody wywłaszczenie nieruchomości stanowi pozbawienie albo ograniczenie, w drodze indywidualnego aktu administracyjnego, prawa własności, prawa użytkowania wieczystego lub innego prawa rzeczowego na nieruchomości, przy czym wywłaszczenie nie może być dokonane, jeżeli cele publiczne mogą być zrealizowane w inny sposób niż przez pozbawienie albo ograniczenie praw do nieruchomości. ${ }^{14}$ Oczywiście wywłaszczenie nie wchodzi w grę, gdy prawa, które podlegałyby wywłaszczaniu mogą być nabyte w drodze umowy od podmiotów z tychże praw uprawnionych. Przy wywłaszczeniu dokonywanym w związku z utworzeniem lub powiększeniem parku narodowego kluczowe są aspekty obszarowe, nie zaś ochronne. Wywłaszczenie jest dopuszczalne jedynie, gdy istnieje potrzeba objęcia ochroną określonego obszaru lub powiększenia tego obszaru. $^{15}$

W przypadku niewykorzystania w ciągu 7 lat wywłaszczonych nieruchomości na cele związane $\mathrm{z}$ utworzeniem lub powiększeniem parku narodowego bądź zamiaru wywłaszczenia na inny cel publiczny, grunt może zostać zwrócony pierwotnym właścicielom zgodnie $\mathrm{z}$ procedurami opisanymi w ustawie o gospodarce nieruchomościami.

Zanim jednakże zostanie wdrożone postępowanie wywłaszczeniowe albo dobrowolna sprzedaż gruntów pod utworzenie bądź powiększenie obszaru parku narodowego, wpierw musi być przeprowadzona procedura wydania stosownego rozporządzenia Rady Ministrów określona w art. 10 ust. 1 ustawy o ochronie przyrody. Zgodnie zaś z art. 10 ust. 2 przedmiotowej ustawy, przed przyjęciem przez Radę Ministrów rozporządzenia należy dokonać uzgodnień z właściwymi miejscowo organami uchwałodawczymi jednostek samorządu terytorialnego. W związku z faktem, iż od 1999 roku samorząd terytorialny jest trójstopniowy, oznacza to uzyskanie zgód odpowiednich rad gmin, rad powiatów oraz sejmików wojewódzkich. ${ }^{16}$ Ponadto powinno się zasięgnąć niewiążących opinii organizacji społecznych. Co ciekawe, możliwa jest również likwidacja lub zmniejszenie obszaru parku narodowego (przeprowadzana według tej samej procedury), jednakże jedynie w przypadku bezpowrotnej utraty wartości przyrodniczych i kulturowych.

\footnotetext{
14 B. Ziemianin, K.A. Dadańska, Prawo rzeczowe, Warszawa 2008, s. 120-121.

15 B. Rakoczy, Gospodarowanie nieruchomościami na obszarze parku narodowego, „Państwo i Prawo” 2012, nr 9 , s. 69 .

16 Z. Leoński, Samorząd terytorialny w RP, Warszawa 2006, s. 119-124, 148-150, 156-160.
} 


\section{Postulaty zmian w regulacja prawnych dotyczących powiększania parków narodowych z uwzględnieniem realiów praktyki gospodarczej}

Ustawa o ochronie przyrody $\mathrm{w}$ obecnym kształcie w praktyce uniemożliwia tworzenie nowych parków narodowych lub powiększanie obszarów parków narodowych już istniejących. Przyczyną takiego stanu rzeczy jest istniejąca, wspomniana już wcześniej, procedura uzgodnień organów uchwałodawczych jednostek samorządu terytorialnego, które są niechętne tworzeniu parków narodowych i ich otulin przede wszystkim ze względu na ograniczenia w zakresie prowadzenia działalności gospodarczej i możliwości blokowania przez dyrektorów parków narodowych zmian w miejscowych planach zagospodarowania przestrzennego.

Przypadki blokowania przez jednostki samorządu terytorialnego na gruncie obecnej ustawy o ochronie przyrody zresztą już występowały. Nie udało się powołanie Jurajskiego Parku Narodowego, Mazurskiego Parku Narodowego i Turnickiego Parku Narodowego, a ponadto upadł projekt powiększenia obszaru Białowieskiego Parku Narodowego. ${ }^{17}$

W 2010 roku powstał obywatelski projekt ustawy o zmianie ustawy o ochronie przyrody, ${ }^{18} \mathrm{~W}$ myśl którego przede wszystkim procedurę uzgodnień przy tworzeniu i z jednostkami samorządu terytorialnego zastąpić miałaby procedura uzyskiwania (niewiążących dla rządu) opinii jednostek samorządu terytorialnego, zaś brak uzyskania opinii $\mathrm{w}$ terminie 30 dni byłby uznawany za milczącą zgodę. Niestety wątpliwe jest, by samorządy terytorialne oraz społeczności lokalne wyraziły zgodę na takie rozwiązanie.

Niewątpliwie z punktu widzenia tradycyjnej struktury gospodarki tworzenie parków narodowych i ich otulin stanowi znaczną barierę, zwłaszcza poprzez utrudnione procedury zmian miejscowych planów zagospodarowania przestrzennego. Z drugiej jednak strony większość gałęzi gospodarki szkodliwych dla środowiska albo jest obecnie schyłkowa, albo modernizuje swoje technologie produkcji na możliwie najmniej kolidujące ze środowiskiem naturalnym. Utworzenie nowych parków narodowych i powiększanie istniejących może być raczej zachętą dla potencjalnych turystów i przyczynić się w szczególności do rozwoju agroturystyki.

Ponadto, bardziej z porządkujących względów, pożądanym byłoby połączenie treści art. 7 ust. 1 ustawy o ochronie przyrody z art. 6 ust. $9 \mathrm{~b}$ ustawy o gospodarce nieruchomościami $\mathrm{w}$ jeden spójny przepis $\mathrm{w}$ ustawie o gospodarce nieruchomościami, będącej wszakże podstawową ustawą w zakresie wywłaszczeń. 
Ekonomiczno-prawna analiza racjonalności regulacji dotyczących powiększania obszarów...

\section{Podsumowanie}

Zasoby naturalne, w szczególności ziemia, od wieków stanowią jeden z podstawowych czynników produkcji, jednakże na obecnym etapie rozwoju gospodarczego stwierdzić należy, iż są one nawet bardziej istotne w kontekście ich ochrony. Racjonalne gospodarowanie tymi zasobami częstokroć wymaga korzystania z prawnych form ochrony przyrody, jakimi są parki narodowe. Jednakże tworzenie nowych parków narodowych oraz powiększanie parków narodowych już istniejących jest prawnie wyjątkowo skomplikowane.

Wyczerpanie procedury uzgodnienia przy zamierzonym tworzeniu lub powiększeniu obszaru parku narodowego niemalże co do zasady natrafia na veto jednostek samorządu terytorialnego, jednostek, które na każdym ze swoich trzech szczebli są w stanie zablokować inicjatywy na rzecz parków narodowych.

Nawet w przypadku, gdyby Rada Ministrów utworzyła bądź powiększyła park narodowy, to procedura wywłaszczania uprawnionych z tytułu prawa własności, czy też użytkowania wieczystego jest na tyle długotrwała, że może trwać latami i wywołuje psychologiczny opór u osób wywłaszczanych, który następnie negatywnie wpływa na obiór zamysłów powiększania parków narodowych.

Obawy lokalnych społeczności budzą również restrykcje w zakresie miejscowych planów zagospodarowania związane $\mathrm{z}$ istnieniem parków narodowych.

Częstokroć na przeszkodzie inicjatywom na rzecz parków narodowych lokalne społeczności przeciwstawiają względy natury ekonomicznej, aczkolwiek na obecnym stopniu rozwoju gospodarczego są one przynajmniej częściowo nieuzasadnione.

Tak naprawdę nie powinniśmy sobie jednak zadawać pytania, jakie są koszty alternatywne tworzenia lub powiększania parków narodowych, lecz jakie są koszty alternatywne braku ich tworzenia dla przyszłych pokoleń i środowiska naturalnego.

\section{BIBLIOGRAFIA}

Goetel W., Parki narodowe w Polsce, [w:] W. Szafer (red.), Ochrona przyrody. Rocznik 26, Kraków 1959.

Leoński Z., Samorząd terytorialny w RP, Warszawa 2006.

Mały rocznik statystyczny 2011, GUS, Warszawa 2011.

Olaczek R., Słownik szkolny, ochrona przyrody i środowiska.

Rakoczy B., Gospodarowanie nieruchomościami na obszarze parku narodowego, „Państwo i Prawo” 2012, nr 9.

Rekowski M., Mikroekonomia, Poznań 2005.

Samuelson P.A., Nordhaus W.D., Ekonomia. Tom 1, Warszawa 2004.

Symonides E., Ochrona przyrody, Warszawa 2008. 


\section{Łukasz Borkowski, Piotr Chmielewski}

Zgorzelski M., Uwagi na temat roli otulin w polskim, przestrzennym systemie obszarów chronionych, „Prace i Studia Geograficzne” 2011, T. 46.

Ziemianin B., Dadańska K.A., Prawo rzeczowe, Warszawa 2008. 
Ekonomiczno-prawna analiza racjonalności regulacji dotyczących powiększania obszarów...

\section{THE ECONOMIC ANALYSIS OF LAW AND RATIONALITY OF LEGAL REGULATIONS CONCERNING ENLARGEMENT OF POLAND'S NATIONAL PARKS - AN OUTLINE}

The issue of the enlargement of existing national parks in Poland, along with the creation of new parks, is a crucial element in protecting the country's strategic natural resources. This issue is an interdisciplinary one and must be seen not only from the environmental point of view but also from the standpoint of social and economic impact. Where lack of agreement on the enlargement of a national park occurs it is inevitable that an expropriation procedure will ensue, limiting the constitutional right of property. Even the protective cover of national parks considerably reduces economic activity, for example by restricting local plans for spatial development. The existence of a realistic procedure for the enlargement of national parks as well as the creation of new parks, is necessary for preserving the country's natural resources even though it needs significant legislative changes.

Keywords: national park, expropriation, public purpose, property law, environmental protection 